\title{
Unexpected diagnosis of fetal malformations: therapeutic itineraries
}

\section{| ${ }^{1}$ Olga Luiza Bomfim, ${ }^{2}$ Orlando Coser, ${ }^{3}$ Maria Elisabeth Lopes Moreira |}

\begin{abstract}
Ultrasonography was a technological breakthrough for obstetrics, allowing visualization of fetal structures. However, the lack of a systematic approach to obstetric ultrasound examinations causes in Brazil, pregnant women do the exam on their own, which can sometimes lead to unexpected diagnosis of fetal malformation. In order to describe the reaction of women when surprised by the diagnosis of fetal malformation and therapeutic itineraries that follow, we conducted a study with nine pregnant women after ultrasound confirmation of fetal malformation. Through semi-structured interviews and content analysis of the narratives, the following categories were identified: motivation to perform ultrasonography; care at the referral; and coping strategies from the confirmation of fetal malformation. The interviews revealed failure to comply with the correct sequence of the prenatal care process. Definition of suitable moment for ultrasound test and guidance at each stage of pregnancy now represent a challenge for the improvement of perinatal care.
\end{abstract}

> Key words: pregnancy; high risk; ultrasonography; prenatal care

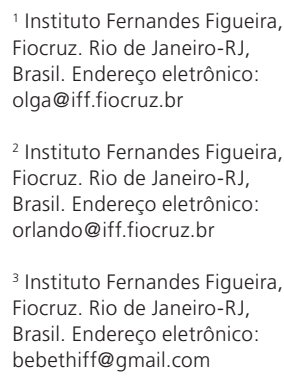

1 Instituto Fernandes Figueira, Fiocruz. Rio de Janeiro-RJ, Brasil. Endereço eletrônico: olga@iff.fiocruz.br

${ }^{2}$ Instituto Fernandes Figueira Fiocruz. Rio de Janeiro-RJ, Brasil. Endereço eletrônico: orlando@iff.fiocruz.br

${ }^{3}$ Instituto Fernandes Figueira, Fiocruz. Rio de Janeiro-RJ, Brasil. Endereço eletrônico: bebethiff@gmail.com 


\section{Introduction}

The development of ultrasound (US) has represented one of the main technological advancements in the last 50 years for medicine, especially for obstetrics, since it allows viewing fetal structures in great detail, thus turning the fetus into a real patient (GOLDBERG, 2000).

Although the incidence of fetal malformations is relatively low (2-4\%), their epidemiological importance has increased due to their current role in infant mortality rates (HOROVITZ; LLERENA JR; MATTOS, 2005). In Scandinavian countries and Japan, where infant mortality is around 10 per 1,000 live births, genetic disorders account for approximately 50\% of infant deaths. In Brazil, in states like Rio Grande do Sul and Rio de Janeiro, where the infant mortality rates are below 20 per 1,000, genetic disorders are already the second cause of infant mortality and thus require special attention (GIUGLIANI, 2002).

In 2002, a systematic review of pregnant women's perceptions concerning obstetric ultrasound conducted by Garcia et al. (2002) identified 74 studies. They observed that unlike other forms of fetal screening, the test entices patients because early visualization confirms both the pregnancy itself and the well-being of the fetus. However, when the test detects some fetal alteration, feelings of disappointment, surprise and anxiety may be negatively intensified.

In Brazil, there is no systematic approach or official regulation concerning ultrasound testing during prenatal care. Thus, ordinary ultrasound tests performed in health services, radiology clinics, or even physicians' office can detect congenital anomalies, or even fail to detect them when they exist. According to good clinical and laboratory practices, the attending obstetrician with a given purpose according to the gestational period should order both ultrasound and other diagnostic tests, and the patient should return to her obstetrician with the result. However, at their own initiative, pregnant women frequently turn to ultrasound clinics to perform the test in order to confirm the pregnancy or find out the baby's sex. Moreover, the test is usually performed under such conditions, even with no formal indication or attending physician's order.

Based on the narratives of nine pregnant women, the current study describes their trajectories, beginning with the ultrasound test indicating the unexpected diagnosis of congenital malformation all the way to the referral unit in Fetal 
Medicine. This article was drawn from the dissertation presented at Instituto

Fernandes Figueira / Fiocruz by one of the authors (BOMFIM, 2009).

\section{Methodology}

A comprehensive approach was used, based on life narrative analysis, which allowed highlighting the time-line of events in the different stages of care (MINAYO, 2008; HYDÉN, 1997). Nine semi-structured interviews were performed, and data were collected on the obstetric and family history using a questionnaire with the following variables: name, age, marital status, current gestational age, fetal diagnosis, and family history of malformation. The narratives were submitted to the content analysis technique, adapted from Bardin (1977), with categorization of the elements. The study also assessed issues related to the flow of care and set of complementary information. The interviews were held from August to December 2008, until obtaining saturation of answers.

The aim was to understand how women experiencing this situation saw the process itself, the concerns it aroused, the rushed decisions it precipitates, and the paths of care it helps build. With these objectives done, we would describe the therapeutic pathway followed by these patients, which converges with what is called, in the anthropological literature, the therapeutic itinerary (CABRAL et al., 2011). According to Alves \& Souza, a social anthropological literature on therapeutic itineraries aims to interpret the processes by which individuals or social groups choose, evaluate, and adhere or not, certain proposals for treatment (ALVES; SOUZA, 1999). In this context, we chose to work with this concept of "itineraries" considering that in the current organization of health services, this problem is solved by the authorities and by pregnant women from different assumptions and joints.

The study subjects were pregnant women registered at the referral unit after ultrasound confirmation of fetal malformation. The study excluded women who chose to return to their original health unit and those whose fetuses had been diagnosed with anencephaly, since a specific study was being performed during the same period with pregnant women whose fetuses had this diagnosis (the idea was thus to avoid subjecting them to two concurrent studies).

The interviews were performed by the first author, Bomfim, and lasted until saturation of answers was achieved. The flow of consultations at the referral 
unit for confirmation of malformations is based on prenatal outpatient screening and ultrasound scheduling. After performing the test, referral to the prenatal service, and the decision to enroll in the referral unit, 11 pregnant women were invited. Three failed to appear on the scheduled date. One of these returned to reschedule her interview, and the other two, who lived in remote towns, did not reappear. On the day the invitation was issued, it was explained that the interview should be conducted only with the women themselves. This decision was made because the presence of anyone else in the interview setting would have altered the woman's answers or personal testimony.

Informed consent was read and explained to the patient, and the interview only began after she had agreed and signed the form. A data collection form was completed, that proved to help both initial knowledge and the open questions. According to the narrative technique, the triggering topics valued reconstruction of the timeline, beginning with confirmation of the pregnancy and the unexpected diagnosis as an event and its possible outcomes.

The research project was approved by an Ethics Committee for Research Involving Human Beings (no. CAEE 0018.0.008.000-08).

\section{Results and Discussion}

\section{Characteristics of study participants}

Participants' age ranged from 17 to 42 years (mean 27.8 years). As for marital status, two lived in the same house with the husband. Gestational age at the time of the interview ranged from 22 to 32 weeks (mean 27 weeks). This was the first pregnancy for six of the women.

Some issues need to be clarified before presenting the results. In Brazil, exclusively physicians perform ultrasound tests and there are no ultrasound technicians that perform the test, and the patient returns to her obstetrician for information on the diagnosis. The fact that physicians perform ultrasound tests changes the relationship between the examiner and the patient, given that the results, which are immediate visual images, can be announced at the very moment in which the test is being performed, and other clarifications can be provided immediately after the test is concluded. 
After conducting, transcribing, and reading the interviews, we grouped the following categories:

Table 1. Categories obtained from analysis of the interviews

\begin{tabular}{|l|l|l|l|}
\hline \multicolumn{1}{|c|}{ Categories } & \multicolumn{3}{c|}{ Subcategories } \\
\hline $\begin{array}{l}\text { 1. Performing the } \\
\text { ultrasound test } \\
\text { the pregnancy }\end{array}$ & $\begin{array}{l}\text { Confirmation of } \\
\text { the baby's sex }\end{array}$ & $\begin{array}{l}\text { Confirmation of the test } \\
\text { result }\end{array}$ \\
\hline 2. Referral unit & Referral & $\begin{array}{l}\text { Reception and } \\
\text { difficulties }\end{array}$ & Test room setting \\
\hline $\begin{array}{l}\text { 3. Coping } \\
\text { strategies }\end{array}$ & Religiosity & $\begin{array}{l}\text { Diminutive } \\
\text { Incomplete diagnosis }\end{array}$ & $\begin{array}{l}\text { Support network } \\
\text { Expectations towards care }\end{array}$ \\
\cline { 2 - 4 } & Frustration, guilt & Hope, miracle & Fetal versus maternal risk \\
\hline
\end{tabular}

\section{Ultrasound test performed to confirm the pregnancy}

Ultrasound as an option to confirm the pregnancy occurs when the woman only believes she is pregnant after she has the test.

So I didn't really believe [I was pregnant]... I mean it was something in my head. So people were saying... saying... what if [you're pregnant]? So I had an ultra (sic), and there it was, pregnancy... (RS).

In the systematic review by Garcia et al. (2002), the initial ultrasound test also emerged as a possibility for early visual confirmation of the pregnancy, as if by seeing the fetus the woman could actually feel pregnant. Lalor et al. (2007) also indicate that women view the ultrasound test as a possibility for "seeing" the baby. At this moment, the test is not a tool for prenatal care, but one of social recognition. In the ethnographic study by Chazan (2008), visualization of the embryo became a possibility for making the pregnancy real to the woman, and obstetric ultrasound had become a form of "consumption" and "leisure".

The narratives analyzed here corroborate those studies (GARCIA et al., 2002; LALOR et al., 2007; CHAZAN, 2008), but with an additional aggravating factor: some of the women had performed an ultrasound test even before initiating their prenatal care, thus without any physician referral. 

it, because I hadn't started prenatal yet. Or even before my second [ultrasound], either (VDG).

Thus, these women appeared at the prenatal clinic after having an ultrasound test at their own initiative, in a clear reversal of the proper and necessary steps in prenatal care and good practices. Inappropriately, ultrasound is easy to access in Brazil, since the test does not need a physician's order or referral (which various ultrasound clinics do not require). Ultrasound testing is also affordable. These factors contribute to a haphazard demand, turning the test into a banality with no orientation or criteria, when it is supposed to be part of systematic prenatal workup, with specific indications for each period of the pregnancy. Women ask to have the test for personal reasons and thus miss the opportunity to clarify the test's specificity and limitations at each gestational age.

Another reason that performing an ultrasound test attracted the women was finding out the sex of the baby. Four women had thus gone to ultrasound clinics out of mere curiosity, with no clinical or laboratory justification:

I went on my own, for myself, because I wanted to know the baby's sex (DBSR).

I had [an ultrasound test] out of curiosity, to find out [the baby's] sex (VDG).

Identification of the baby's sex represents a key moment in its public existence. It allows choosing the name, baby clothes, and celebrations.

Another issue is repetition of the tests. Repeat ultrasound emerged as resource in the face of the difficulty in admitting and accepting a fetal abnormality detected in a previous test:

I don't believe at all... [that the test is abnormal]. I'm going to have one somewhere else (SMPS).

I had ultrasound tests at several places, to be certain of the diagnosis (KLPS).

These quotes reveal a clash between better clarification of what has already been said and the hope that by changing the place where the test is performed, the diagnosis will also change (for the better).

In Brazil, the Technical Manuals for Qualified and Humanized Prenatal and Postpartum Care, published by the Ministry of Health (2005/2006), emphasize that ultrasound during pregnancy is an ordinary test, but without sufficient evidence to indicate its routine use in prenatal services. That is, its use would only help reduce perinatal morbidity and mortality in high-risk pregnancies. As 
for the current scientific evidence for early detection of fetal malformations, this

benefit is not an issue in Brazil, since interruption of pregnancy on grounds of fetal malformation is not yet legally permitted, except in cases of anencephaly or rape, upon judicial authorization.

The American Institute of Ultrasound in Medicine, American College of Radiology, American College of Obstetricians and Gynecologists (2007), and Royal College of Obstetricians and Gynaecologists (2008) have elaborated joint guidelines and procedures according to which, among other issues, fetal ultrasound should be performed with a clinical indication and the test should be ordered by a physician or other authorized health professional according to local practice, with indications focusing on each gestational period. Those four institutions recommend that a specialized professional trained in fetal medicine performs the test, and at least one test should be performed to confirm the gestational age. When a diagnosis of fetal malformation occurs, the parents should benefit from a multidisciplinary discussion at the test service itself or be referred to a tertiary unit.

The growing possibilities for performing obstetric ultrasound suggest that the agencies in charge of monitoring both the technical quality and pertinence of indicating the tests should elaborate and discuss the standards for specific conducts in this segment of healthcare in Brazil.

\section{Referral to specialized care}

Referral to a specialized unit occurred from the primary care site as a possibility for diagnostic clarification, better follow-up, and treatment. The Fernandes Figueira Institute is a Brazilian reference hospital for congenital malformations that receives referrals from all over the country. Some quotes from the narratives indicate that public knowledge considers the hospital as the place where the problems could be solved, regardless of their severity. Referral was accepted on grounds that it would be the best choice under the circumstances, with care by specialists, and due to the impossibility of receiving adequate answers at the original prenatal services. These arguments were even used to justify the patients coming from a far, sometimes 150 kilometers or more.

Now it's really difficult. It's really far, really tiring (SMPS).

It's far for me. In my opinion, we have to stay here for a long time. I thought it took a long time (PSG). 
Lalor et al. (2007) also cited the issue of distance from the patient's home to the reference hospital in the study. In some cases, when prenatal or childbirth care at the reference hospital did not offer any additional prospects of survival for the newborns, the pregnant women were offered the possibility of returning to their original prenatal service in order to decrease their travel burden. However, some women saw this as a break in their treatment. This issue merits further investigation in Brazil.

High expectations are created in the original prenatal services concerning consultation with a specialist in fetal medicine. According to the narratives, the specialist is supposed to be the professional who really knows the answers. Thus, waiting for an appointment becomes a factor for anxiety and distress, indicating that whenever possible contact with the specialist should occur within 24 hours (VAN DER ZALM; BYRNE, 2006; LALOR et al., 2007).

Another issue reported by some women after the first test at the reference hospital was a feeling of frustration over the speed with which the test was performed.

I can't give more details, because they didn't run the complete test (KLPS).

They did the morphological [test] real quick (SMPS).

Their expectation was that spending more time on the test would mean a betterquality test and more professional dedication. However, since it is a confirmatory diagnostic test aimed at determining the appropriateness of monitoring the patient at the reference hospital, and because it is performed by specialists in diagnosing malformations, the test is generally quicker than that done previously by less experienced hands. This fact suggests a communications gap in this confirmatory test at the reference hospital, namely that the patients were not informed as to the specific purpose of the diagnostic confirmation. The "complaint" about the short test time was also a function of the long delay between the first visit to the reference hospital and the ultrasound appointment (approximately one month). This delay further increased the patients' expectations concerning the procedure.

A study by Van der Zalm \& Byrne (2006), in which 13 pregnant women narrated their experience with the ultrasound-screening test by which fetal malformations were detected, narrative analysis identified the following categories: timing of the ultrasound test, the test room setting, communication of bad news, and concern over continuity of care. The setting and the health 
team's behavior were factors that helped determine whether patients perceived the experience as positive or negative.

In our study, the issue of the test setting did not emerge as a category. Even with attempts at probing during the interviews, the answers focused on personal care and treatment. A set of circumstances appears to have contributed favorably to attenuating issues relating to the test setting alone, mainly the fact that, as a confirmatory test for the fetal diagnosis, it is performed by medical specialists who do not work in silence like the ultrasound technicians who perform the tests in other countries, and that all the women were already familiar with a similar setting and entered the ultrasound suite with an accompanying person.

\section{Coping strategies}

Analysis of the women's narratives revealed the coping strategies each one developed. This was the category that showed the greatest content density, covering the reconstruction of events over the course of a defined period, namely the pregnancy. One of these categories is religiosity. Comfort through prayer or belief in God was present at some moment in all of the interviews, possibly from the perspective approached by Hawkins (1990), or the paradigm of crisis and regeneration. When serious illness leads individuals to reevaluate life's meaning and values, the religious or spiritual narrative emerges.

Every night before I go to bed, I pray...I ask God to help cure him... So I'm placing him in God's hands (ACJCC).

Another strategy to attenuate the diagnosis is to refer to it in the diminutive: This small hole in the spinal column... (SMPS).

A variation on this strategy is to consider only a fragment of the medical information, as in "the cleft lip..." - (ACJCC), disregarding other diagnostic findings, which in this case was holoprosencephaly, a congenital anomaly that affects brain development and the body's midline, but with a more serious impact on development and prognosis.

Disappointment with the baby's sex also appeared as a strategy to shift the focus of frustration over the diagnosis of fetal malformation to frustration with the sex, when the latter differed from the parents' wishes.

Another issue was the family or social support network, always present, on varied degrees. 
I think it's wonderful for him to go in with me. He's by my side and all. This is good for me as a woman. Because to take a blow like this all alone...is really hard... but when there's someone to share this pain... The pain stays, but it's lighter, you know, to bear (DBSR).

As for expectations towards care and treatment, even when there is some doubt about whether the referral unit is the best place, there are few if any alternatives in the Brazilian healthcare scenario:

I just hope they see to my problem for me to take care so my baby will be born normal (PGBB).

Here, the narrative resumes the expectation that the reference hospital will also represent the possibility of correcting the original diagnosis.

\section{Personal reactions}

Personal reactions are actually part of coping strategies, but they appear as an important subcategory, since they combine emotional components and hopeful expectations: the initial shock, a feeling of frustration and guilt, and confusion between fetal and maternal risk.

The day I found out I left the clinic, and it was such a big shock that I froze... I went numb (KLPS).

In Lalor et al. (2007) this initial shock also appeared in all the women when they learned that something was wrong with their babies.

I really believe in miracles. A miracle can happen! Yes! Just imagine what a turnaround, look, my perfect baby! (DBSR).

Unlike other moments in life, anticipation of fetal diagnosis is frequently not experienced as a concrete reality. This is a very complex statement, based on a clinical assumption that our practice long testimonies. It is possible to understand this in a Kantian sense, that the information provided goes beyond what the patients could imagine, and therefore its subjective apprehension is not completed. Those facts have great chance to be lived as a traumatic experience, in a Freudian sense. Summarizing, patients are confronted with the need to subjective apprehend something that goes beyond its symbolic resources. The process is traumatic because the comprehension of the information about the malformation brings, at the same time, et pour cause, consciousness of the impossibility of the baby's healthy live. ${ }^{1}$ 
This brings to the women possibility to establish a different line of movements

until the baby's birth: shock and disappointment, alternating with hope and the possibility of a miracle.

\section{Final Remarks}

The pathway described by women, beginning with the first ultrasound test, the reasons for taking it, attraction to the test and the ease in submitting to it, all showed undesirable variability. This reveals a lack of clarity in the guidelines and procedures for using diagnostic resources, exposing pregnant women to improper situations during perinatal care. The opportunity is thus missed for precise indication of the ultrasound test, with the necessary clarifications: the test's indication and purpose in each stage of pregnancy, what to expect of the images, its limitations at different gestational ages, and the possibility of accurately detecting fetal abnormalities. With such a tortuous beginning, namely the unexpected identification of a fetal malformation, few possibilities exist for referring the patient to a formal reference unit because a regionalized and hierarchical network of perinatal care has still not been established in Brazil. The study showed an obvious lack of systematic regulation for both indicating and performing obstetric ultrasound tests and providing appropriate care for these pregnant women.

Meanwhile, the flow of care at the high-complexity hospital that currently absorbs the referrals fails to consider what was identified in the literature (and in the current study), namely the urgent need for immediate referral to a specialist in fetal medicine following a dubious ultrasound diagnosis. Currently, the Brazilian Ministry of Health has expanded access to prenatal ultrasound through the recently deployed "Projeto Cegonha". However, maternal reference is still a problem, since the network does not yet have enough slots in the system to meet this type of patients and the reference is given by inadequate ways.

From the perspective of individual care for the pregnant woman, expectations turn to frustration due to ignorance concerning the purpose of both the original ultrasound test and the confirmatory test at the specialized center. Planning prenatal care as a whole could be expedited if the patient received appropriate information at each stage of her pregnancy. After an unexpected diagnosis, referral to a specialized center and the establishment of a proper treatment plan 
should be provided immediately. Pregnancy lasts for a finite period, and if earlier doubts are cleared up, the greater the odds of better planning.

At this point, the context of timely care becomes important, considering that Brazilian legislation does not allow the interruption of pregnancy in cases of congenital malformations, except in cases of anencephaly, and even in the latter case the court authorization tends to come late, often in advanced stages of the pregnancy. Another important issue is that Brazil is a country with a Catholic majority, which in turn influences the woman's decision concerning interrupting the pregnancy, thus involving the need to organize services so as to provide comprehensive medical, social, and psychological care.

In relation to the baby's prognosis, the concerns alternate between unconditional hope for a miracle, on one side, and anxiety on the other. In a phase ripe with hypothetical scenarios, receptiveness and support from the health service, not only for the patient but for her family as well, represent a positive point that should be maintained and included at all opportunities during the health team's training.

A challenge for perinatal services is to establish a line of care in which all team members know their roles. Comprehensive knowledge of the healthcare network, with its possibilities for referral and counter-referral and from the perspective of public policies allied with the pregnant women's own perceptions, should help improve obstetric care in Brazil. Knowledge brought by this research reveals that the pathway followed by women confronted with the unexpected diagnosis of a fetal malformation subverts health service policies and guidelines for maternal health service provision. ${ }^{2}$

\section{References}

ALVES, P.C.B.; SOUZA, I.M.A. Escolha e avaliação de tratamento por problema de saúde: considerações sobre itinerário terapêutico. In: RABELLO, M.C.; ALVES, P.C.B.; SOUZA, I.M.A. Experiência de Doença e Narrativa. Rio de Janeiro: Fiocruz, 1999. p. 125-138.

AMERICAN INSTITUTE OF ULTRASOUND IN MEDICINE. AIUM practice guideline for the performance of obstetric ultrasound examinations. Available at: <http://www. aium.org/resources/guidelines/obstetric.pdf> Access on: March 1, 2013.

BARDIN, L. Análise de conteúdo. Lisboa: Edições 70, 1977.

BOMFIM, O.L. de C. A antecipação ultrassonográfica de malformação fetal sob a ótica da mulher. Dissertação (Mestrado em Saúde da Criança e da Mulher) - Pós-Graduação em 
Saúde da Criança e da Mulher, Instituto Fernandes Figueira, Fundação Oswaldo Cruz. Rio de Janeiro, 2009.

BRASIL. Ministério da Saúde. Manual técnico pré-natal e puerpério atenção qualificada e humanizada. Brasília: Ministério da Saúde, 2005.

- Ministério da Saúde. Manual técnico pré-natal e puerpério atenção qualificada e humanizada. Brasília: Ministério da Saúde, 2006.

CABRAL, A.L.V. et al. Itinerários terapêuticos: o estado da arte da produção científica no Brasil. Ciência \& Saúde Coletiva, v. 16, n. 11, p. 4.433-4.442, 2011.

CHAZAN, L.K. “É... tá grávida mesmo! E ele é lindo!” A construção de "verdades” na ultra-sonografia obstétrica. Hist Cienc Saúde-Manguinhos. Rio de Janeiro, v. 15, n. 1, p. 99116, jan-mar 2008.

GARCIA, J. et al. Women's views of pregnancy ultrasound: a systematic review. Birth, v. 29, n. 4, p. 225-50, 2002.

GIUGLIANI, R. A importância da genética médica e do estudo de defeitos congênitos. In: LEITE, J.C.L.; COMUNELLO, L.N.; GIULIANI, R. (Orgs.). Tópicos em defeitos congênitos. Porto Alegre: EdUFRGS, 2002. p. 11-14.

GOLDBERG, B.B. Obstetric US Imaging: The past 40 years. Radiology, v; 215, p. 62229, 2000.

HAWKINS, A.H. A change of heart: the paradigm of regeneration in medical and religious narrative. Perspect Biol Med., v. 33, n. 4, p. 547-59, 1990.

HOROVITZ, D.D.G.; LLERENA JR., J.C.; MATTOS, R.A. Atenção aos defeitos congênitos no Brasil: panorama atual. Cad Saúde Pública, v. 21, n. 4, p. 1.055-64, 2005.

HYDÉN, L-C. Illness and narrative. Sociol Health Illn., v. 19, n. 1, p. 48-69, 1997.

LALOR, J.G.; DEVANE, D.; BEGLEY, C.M. Unexpected diagnosis of fetal abnormality: women's encounters with caregivers. Birth, v. 34, n. 1, p. 80-8, 2007.

LONGUENESSE, B. Kant and the capacity to judge: sensibility and discursivity in the transcendental analytic of the Critique of Pure Reason. Princeton: Princeton University Press, 1998.

MINAYO, M.C. de S. O desafio do conhecimento. São Paulo: Hucitec, 2008.

ROYAL COLLEGE OF OBSTETRICIANS AND GYNAECOLOGISTS. Clinical standards: advice on planning the service in obstetrics and gynaecology. London, 2002. Available at: <http://www.aogm.org.mo/assets/Uploads/aogm/Guidelines/RCOG--UK/RCOG-Clinical-Stndards-Advice-on-Planning-the-Service-in-Obstetrics-andGynaecology.pdf> Access on: March 1, 2013.

VAN DER ZALM, J.E.; BYRNE, P.J. Seeing baby: women's experience of prenatal ultrasound examination and unexpected fetal diagnosis. J Perinatol., v. 26, p. 403-08, 2006. 
${ }^{1}$ For a philosophical explanation of an impossibility of subjective apprehension, see Longuenesse (1998, especially p. 361).

${ }^{2}$ O. Bomfim participou da coleta e análise dos dados, e elaboração do artigo. O. Coser e M.E.L. Moreira participaram da análise e interpretação dos dados, elaboração do artigo, revisão dos elementos contextuais e das referencias bibliográficas. Todos os autores aprovaram a versão final do artigo. 


\begin{tabular}{|c|c|c|c|c|c|c|c|c|c|}
\hline 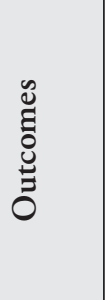 & 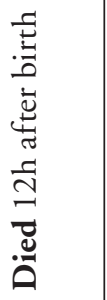 & 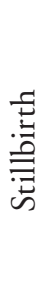 & 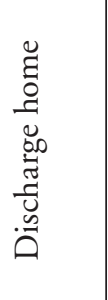 & 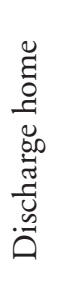 & 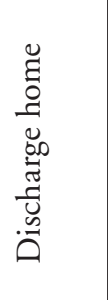 & 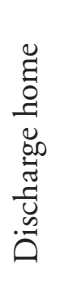 & 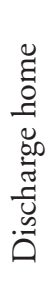 & 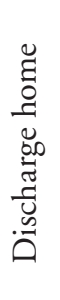 & 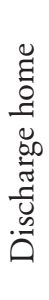 \\
\hline 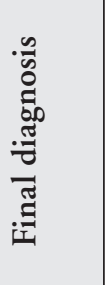 & 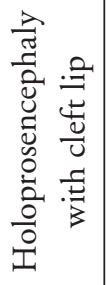 & 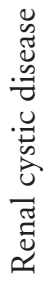 & 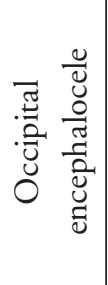 & 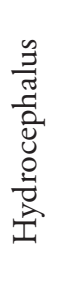 & 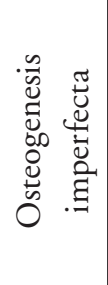 & 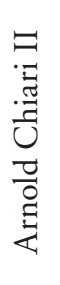 & 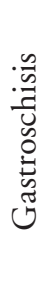 & 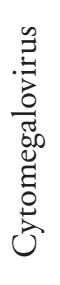 & 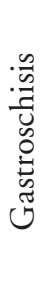 \\
\hline 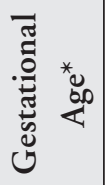 & $\underset{⿱ 丶}{\stackrel{3}{4}}$ & ฉี & 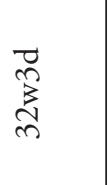 & $\Sigma$ & तె & $\begin{array}{l}\vec{T} \\
\stackrel{+}{3} \\
\stackrel{3}{v}\end{array}$ & 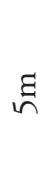 & ణ్ర & $\stackrel{3}{\mathrm{~N}}$ \\
\hline 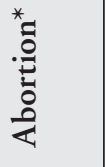 & 0 & 0 & 0 & $\neg$ & 0 & 0 & 0 & 0 & 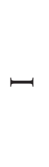 \\
\hline 苞 & 0 & 0 & 0 & $\Xi$ & 0 & 0 & 0 & 0 & - \\
\hline 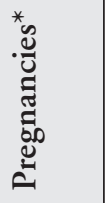 & $\curvearrowleft$ & $\neg$ & $\curvearrowleft$ & $>$ & $\curvearrowleft$ & $\curvearrowleft$ & 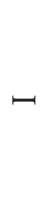 & • & $\Xi$ \\
\hline 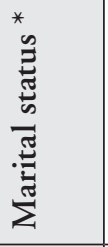 & $\begin{array}{l}\frac{\omega}{\infty 0} \\
\stackrel{\Xi}{\Xi}\end{array}$ & $\begin{array}{l}\frac{0}{00} \\
\stackrel{\Xi}{\infty}\end{array}$ & 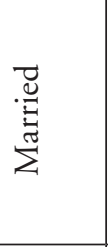 & $\begin{array}{l}\stackrel{\omega}{\infty} \\
\stackrel{\Xi}{\Xi}\end{array}$ & 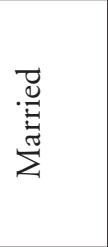 & $\begin{array}{l}\stackrel{0}{\infty 0} \\
\stackrel{\Xi}{\Xi}\end{array}$ & $\begin{array}{l}\stackrel{0}{00} \\
\stackrel{\Xi}{\infty}\end{array}$ & $\begin{array}{l}\frac{0}{\infty 0} \\
\stackrel{\Xi}{\Xi}\end{array}$ & $\begin{array}{l}\stackrel{u}{\infty} \\
\stackrel{\varpi}{\Xi}\end{array}$ \\
\hline${ }^{*}$ & $\beth$ & $\hat{n}$ & $\underset{f}{F}$ & $\curvearrowright$ & $\approx$ & స & $\hat{\sim}$ & $\curvearrowright$ & $\stackrel{\infty}{\sim}$ \\
\hline لِّ & $\neg$ & $\sim$ & $m$ & $\forall$ & $n$ & $\bullet$ & $\Lambda$ & $\infty$ & $a$ \\
\hline
\end{tabular}




\section{$O$ diagnóstico inesperado de malformações fetais: itinerários terapêuticos}

A ultrassonografia representou um avanço tecnológico para a obstetrícia, por permitir a visualização das estruturas fetais. Entretanto, a falta de uma abordagem sistemática para os exames de ultrassom obstétrico faz com que, no Brasil, mulheres grávidas façam o exame por iniciativa própria, o que às vezes pode levar a um diagnóstico inesperado de malformação fetal. Com o objetivo de descrever a reação das mulheres quando surpreendidas pelo diagnóstico de malformação fetal e os itinerários terapêuticos que se sucedem, foi realizado estudo com nove gestantes, após a confirmação ultrassonográfica de malformação fetal. Através de entrevistas semiestruturadas e análise de conteúdo das narrativas, foram identificadas as seguintes categorias: motivação para realizar ultrassonografia; atendimento na unidade de referência; e estratégias de enfrentamento a partir da confirmação de malformação fetal. As entrevistas revelaram uma falha em cumprir com a sequência correta do processo de cuidado pré-natal. A definição do momento adequado para o teste de ultrassom e orientação em cada etapa da gravidez representam um desafio para a melhoria da assistência perinatal.

> Palavras-chave: gravidez; alto risco; ultrassonografia; cuidado pré-natal. 